\section{Influence of Partial Root-zone Saline Irrigation Management on Tomato Yield and Fruit Quality from a Potted-plant Study}

\author{
Rita de Cássia Alves
}

UNESP - Universidade Estadual Paulista, Faculdade de Ciências Agrárias e Veterinárias, Jaboticabal. Depto de Biologia Aplicada à Agropecuária, CEP 14884-900, São Paulo, Brazil

\author{
Ana Santana de Medeiros \\ UFERSA - Universidade Federal Rural do Semi-Árido, Mossoró. Depto de \\ Ciências Ambientais e Tecnológicas, CEP 59.625-900, Rio Grande do Norte, \\ Brazil
}

\begin{abstract}
Mayara Cristina M. Nicolau
UNESP - Universidade Estadual Paulista, Faculdade de Ciências Agrárias e Veterinárias, Jaboticabal. Depto de Biologia Aplicada à Agropecuária, CEP 14884-900, São Paulo, Brazil
\end{abstract}

Francisco de Assis Oliveira

UFERSA - Universidade Federal Rural do Semi-Árido, Mossoró. Depto de Ciências Ambientais e Tecnológicas, CEP 59.625-900, Rio Grande do Norte, Brazil

\section{Leonardo Warzea Lima \\ Department of Biology, Colorado State University, Fort Collins, CO 80523}

Edna Maria M. Aroucha

UFERSA - Universidade Federal Rural do Semi-Árido, Mossoró. Depto de Ciências Ambientais e Tecnológicas, CEP 59.625-900, Rio Grande do Norte, Brazil

\section{Priscila Lupino Gratão ${ }^{1}$}

UNESP - Universidade Estadual Paulista, Faculdade de Ciências Agrárias e Veterinárias, Jaboticabal. Depto de Biologia Aplicada à Agropecuária, CEP 14884-900, São Paulo, Brazil

\section{Additional index words. lycopene, salinity, Solanum lycopersicum, water management}

Abstract. This research aimed to evaluate the yield and quality of tomato plants under different managements of salt stress by adopting the partial root-zone saline irrigation (PRSI) system. The experiment was conducted in a greenhouse at the Universidade Federal Rural do SemiÁrido (UFERSA), Mossoró, Rio Grande do Norte (RN), Brazil. The experimental design was completely randomized, with six treatments and four replicates, totaling 24 plots. The treatments consisted of six different irrigation management regimes using low and high saline water $\left(\mathrm{S} 1-0.5\right.$ and $\left.\mathrm{S} 2-5.0 \mathrm{dS} \cdot \mathrm{m}^{-1}\right)$, applied with or without PRSI, such that one side of the root-zone was submitted to saline water whilst the other side was water low salinity irrigated. For treatments T1 (control), T2 (S2 water), and T3 (alternate irrigation system between S1 and S2, with a cycling period of $15 \mathrm{~d}$ for each one), the PRSI was not applied; T4 (irrigation with S1 and S2, adopting the PRSI system from phase II to phase IV), T5 (irrigation with S1 and S2 in phase II, alternating in phase III; in phase III the inversion of the remaining water was made until the end of phase IV), and T6 (irrigation with S1 and S2, adopting the PRSI system in phase II, with the water switched between low and high saline water every 15 days, remaining until the end of phase IV) treatments were under the PRSI. The number of fruit per plant, fruit weight, fruit longitudinal and transverse diameter, pulp firmness, soluble solids content, titratable acidity, $\mathrm{pH}$, vitamin $\mathrm{C}$, color relation $\left(\mathrm{a}^{*} / \mathrm{b}^{*}\right)$, lycopene, and $\beta$-carotene were determined as parameters for the fruit yield and quality evaluation. Our findings reinforce the importance of the use of PRSI systems followed by irrigation managements without loss of product quality, such as demonstrated by T4 and T5 water managements.
Tomato (Solanum lycopersicum L.) is important as a socio-economic Solanaceae crop worldwide. Total annual tomato production is estimated at 163.96 million metric tons; the largest tomato producers are China $(30.55 \%)$, India $(10.58 \%)$, and the United States $(7.94 \%)$, comprising $49 \%$ of total world production (FAO, 2015). Brazilian tomato production ranked eighth globally, and Brazil is the largest producer of tomatoes in South America. The largest producer in the country is Goiás state, followed by São Paulo and Minas Gerais (IBGE, 2015).

Agricultural production systems must be adapted to the different edaphoclimatic conditions of ecosystems, which may impair both yield and production and ultimately lead to crop losses. In view of this risk, greenhouse farming has become a viable alternative for crop production. The use of greenhouses in commercial agriculture is being widely adopted worldwide because of its numerous benefits, including controlled environment management, production efficiency, and year-round production (Ali, 2008; Costa and Heuvelink, 2004; Silva et al., 2014).

Vegetable crops, including tomato, have a high-water requirement and in most countries, full or supplemental irrigation is necessary for successful vegetable production. The water source can be impaired by high dissolved salt concentration, which may cause serious problems mainly when saline water irrigation is necessary (Silva et al., 2009).

Tomato can be classified as a moderate salt-sensitive crop, possessing a salinity threshold measured as electrical conductivity (EC) at $2.5 \mathrm{dS} \cdot \mathrm{m}^{-1}$, with relative yield losses of $50 \%$ when the substrate salinity is $\approx 7.6$ $\mathrm{dS} \cdot \mathrm{m}^{-1}$ (Maas and Hoffmann, 1977). Tomato yield inhibition under salt-stress conditions, due to saline irrigation water, saline nutrient solution, or excessive fertilizer application, can be related to the number of bunches, fruit per bunch, and average fruit mass (Ehret et al., 2013; Medeiros et al., 2012; Silva et al., 2013b; Zhang et al., 2017).

The deleterious effects of salinity on plant growth may be associated with nutrient imbalance and low osmotic potential $\left(\psi_{\mathrm{S}}\right)$ of soil solution, which reduces both the ability of crops to take up water and also the nutrients' availability (Demiral, 2005; Navarro et al., 2003). In this context, the successful use of saline water supply for crop irrigation depends on the development of new technologies, which could produce high-yield and quality crops. As an overview of the current and potential technologies, the partial root-zone irrigation (PRI) system, in which the root is divided in two or more parts, has been studied in different crop plants, emphasizing the increased water use efficiency and its feasibility (Kirda et al., 2004; Sun et al., 2013a, 2013b; Yang et al., 2012).

Koushafar et al. (2011) demonstrated that the PRI system could be an applicable technique for saline water supply irrigation for hydroponic tomato plants, even if the system's success appears to be dependent on the salinity level and exposure time of roots to 
the salts of nutrient solution and saline water. Several studies have reported the potential economic benefits and increased efficiency of water use in crop plants under the PRI system, since the plants under this partial root-zone stress demonstrated yield gains with low water consumption. Nevertheless, further analyses are needed for a better understanding of the mechanisms connecting stressful conditions and the PRI systems, given that studies on salt stress are scarce.

The use of saline irrigation water through adopting a PRI system is strongly dependent on the salinity range and also the roots' exposure to these salts (Guedes et al., 2015; Koushafar et al., 2011). The aim of this research was to evaluate the yield and quality of tomato plants under different managements of salt stress by adopting a partial root-zone saline irrigation (PRSI) system.

\section{Materials and Methods}

\section{Experimental area}

The study was conducted at the Environmental and Technological Sciences Department at the Universidade Federal Rural do Semi-Árido (UFERSA), in Mossoró, RN, Brazil (lat. $05^{\circ} 11^{\prime} \mathrm{S}$, long. $37^{\circ} 20^{\prime} \mathrm{W}$, altitude $18 \mathrm{~m}$ ). The experiment was conducted in an arc-shaped greenhouse, $7 \mathrm{~m}$ wide by $18 \mathrm{~m}$ long, cover with a transparent low density polyethylene (LDPE) $10 \mathrm{~mm}$ thick, treated to reduce ultraviolet radiation. The lateral and frontal walls were made with antiaphid screens, fixed in $0.30 \mathrm{~m}$ reinforced concrete footer.

\section{Experimental design}

The experimental design was completely randomized, containing six treatments and four replicates. Experimental units consisted of plastic pots with a capacity of $10 \mathrm{dm}^{3}$, one plan per pot, supplemented with a mixture of 3:1 (by volume) coconut powder and sand, respectively (Fig. 1). Coconut powder is an inert substrate with moisture retention properties, and it can promote aeration in the culture medium, and low EC $\left(1.1 \mathrm{dS} \cdot \mathrm{m}^{-1}\right)$ (Nunes, 2000, Amafibra ${ }^{\circledR}$ ). Tomato production has four distinct stages: from seeding to transplanting (phase I -3 to 4 weeks); from transplanting to the beginning of flowering (phase II -4 to 5 weeks); from flowering to the beginning of harvest (phase III -5 to 6 weeks); and from the beginning to the end of the harvest (phase IV -12 to 18 weeks) (Henareh and Hassani, 2014).

Received for publication 17 May 2018. Accepted for publication 25 July 2018.

This work was funded by Conselho Nacional de Desenvolvimento Científico e Tecnológico (CNPq - Grant n. 445978/2014-7). We thank Coordenação de Aperfeiçoamento de Pessoal de Nível Superior (CAPES) (R.C.A.) for the scholarship granted.

${ }^{1}$ Corresponding author. E-mail: plgratao@fcav. unesp.br.

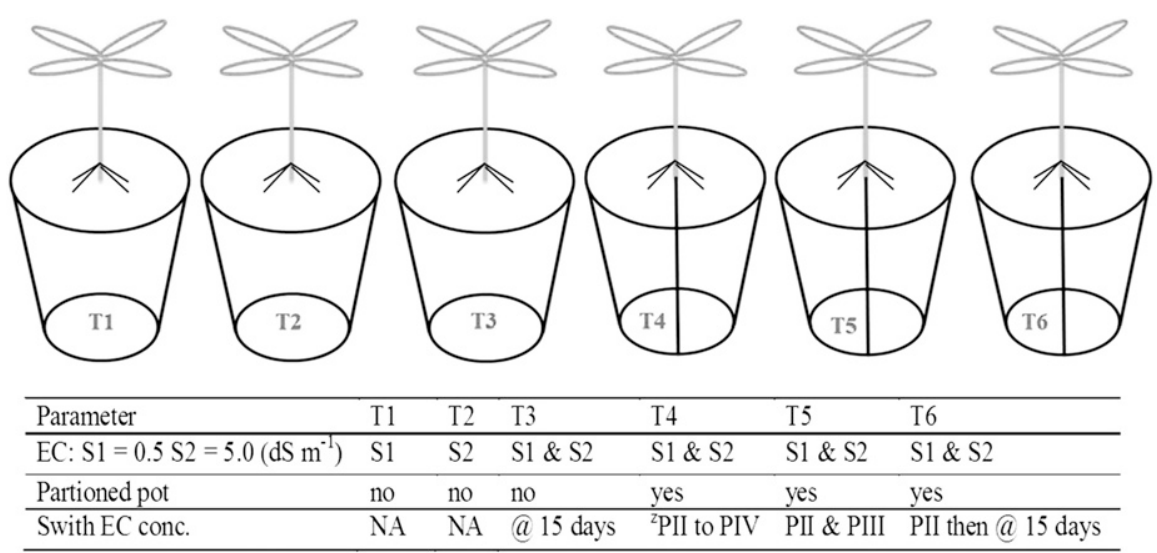

Treatments initiated 11 das after transplanting. ${ }^{2} \mathrm{PI}=$ seeding to transplanting, $\mathrm{PII}=$ transplant to early flowering, $\mathrm{PIII}=$ flowering to harvest, $\mathrm{PIV}=$ harvest.

Fig. 1. Outline of the experimental design.

The treatments consisted of six different irrigation managements using low $(\mathrm{S} 1=0.5$ $\left.\mathrm{dS} \cdot \mathrm{m}^{-1}\right)$ and high saline $\left(\mathrm{S} 2=5.0 \mathrm{dS} \cdot \mathrm{m}^{-1}\right)$ water, applied with or without the partial root-zone saline irrigation (PRSI). PRSI management was used in different ways during distinct phases, described as follows: T1 - Irrigation with water from the campus supply network as a control (S1); T2 Irrigation with saline water (S2); T3 - Alternating irrigation system between these two established salt concentrations (S1 and S2), with a cycling period of $15 \mathrm{~d}$ for each one; T4 Irrigation with $\mathrm{S} 1$ and $\mathrm{S} 2$, using the PRSI system, such that one side of the root-zone was submitted to low saline water (S1) while the other side was high saline water irrigated (S2); the PRSI was used from the phase II to the phase IV; T5 - Irrigation with the two established salt concentrations (S1 and S2), using the PRSI system in phase II, one side of the root zone received water $\mathrm{S} 1$ and the other side of the root zone received water $\mathrm{S} 2$, in phase III the inversion of the remaining water was made until the end of phase IV; T6 Irrigation with the two established salt concentrations (S1 and S2), adopting the PRSI system in phase II, in which each side of the root-zone received both saline water irrigation, with the water switched between low and high saline water every $15 \mathrm{~d}$, remaining until the end of the phase IV. The pots were divided into two compartments, using a plastic film $(125 \mu \mathrm{m})$, bonded laterally with adhesive tape to avoid mixing of water between the divisions of the root system (Fig. 1).

The $5.0 \mathrm{dS} \cdot \mathrm{m}^{-1}$ saline water was obtained by dissolving sodium chloride $(\mathrm{NaCl})$ in water collected in the UFERSA water supply system. The dissolved $\mathrm{NaCl}$ volume used to acquired this specific EC was determined from an artificial water salinization curve, relating the salt concentration with the EC, based on the differential equation from Richards (1954) for the movement of water in unsaturated soils $(\mathrm{C}=640$. $\mathrm{ECa})$, where $\mathrm{C}$ is the salt concentration $\left(\mathrm{mg} \cdot \mathrm{L}^{-1}\right)$ and $\mathrm{ECa}$ is the solution electrical conductivity $\left(\mathrm{dS} \cdot \mathrm{m}^{-1}\right)$. For this procedure, samples of water from the
UFERSA supplying water system were used, considering its EC natural and constant. The added $\mathrm{NaCl}$ was according to the $\mathrm{EC}$ present in the fertigation, so the EC of $5.0 \mathrm{dS} \cdot \mathrm{m}^{-1}$ was always maintained.

\section{Plant material and growth conditions}

The cultivar used was SUPERA F1, a high yielding, early maturing, short season, saladettetype hybrid.

The main root cutting was done in all the plants in phase II, to keep both sides of the root zone uniform without favoring the main root when the plants were placed in the vessels with the divided root-zone. Furthermore, pots were placed in four rows containing eight pots each, distributed in row spacing of $1.5 \mathrm{~m}$ and spacing of $0.70 \mathrm{~m}$ between plants. Each row contained extra vases for border effect.

During the first $10 \mathrm{~d}$ after the transplanting (DAT), all treatments were irrigated using low saline water, to promote uniform seedling development. Beginning 11 DAT, the different levels of saline water irrigation were performed, according to the protocol.

\section{Irrigation and fertigation management}

A drip irrigation system included microtube emitters, which were previously evaluated under regular operating conditions. The emitters were coupled to the $16 \mathrm{~mm}$ supply lines (polyethylene tubes), in which pressure control microvalves were installed, which were used to apply the proper water volume. An autonomous water irrigation system was applied to each type of water, composed of an electric water pump, $500 \mathrm{~L}$ water tank, inline drip tubing $(16 \mathrm{~mm})$ and $0.050 \mathrm{~m}$ polyvinyl chloride tubes, with an average water flow rate of $7.8 \mathrm{~L} / \mathrm{h}$.

We calculated evapotranspiration by measuring the moisture of each cultivation substrate before irrigation and the amount of irrigation water added to each pot to maintain field capacity. Evapotranspiration was calculated according to the soil water balance equation:

$$
\mathrm{ETc}=\mathrm{I}+\mathrm{P}+\mathrm{R} \pm \Delta \mathrm{S}-\mathrm{Dp}
$$

where ETc is daily evapotranspiration under greenhouse conditions $\left(\mathrm{mm} \cdot \mathrm{d}^{-1}\right)$; I is the 
amount of irrigation water $(\mathrm{mm})$; $\mathrm{P}$ is the amount of precipitation ( $\mathrm{mm}$ ) (because the present study was conducted in a greenhouse, precipitation was considered zero); $\mathrm{R}$ is the surface runoff $(\mathrm{mm})$, which was ignored because the surface runoff was minimal or did not occur in the pot; $\Delta \mathrm{S}$ is the change of substrate water depth $(\mathrm{mm})$ between two irrigations at the root zone; and DP is deep percolation ( $\mathrm{mm})$.

After rearrangement, the general equation becomes:

$$
\mathrm{ETc}=\mathrm{I}-\mathrm{Dp}
$$

In these terms, it is assumed that the ETc value between two irrigation events is equal to the amount of water applied to the soil in the treatment in question minus the amount of water drained.

The pots contained a drainage system formed by a layer of crushed stone \#1 and a Bidim drain blanket (Kaytech, South Africa). Irrigation control was performed using adigital timer, and a frequency of six daily events was adopted. A sufficient volume of water was used to cause minimum drainage of $10 \%$ of the total volume applied in irrigation.

Fertilizer application was performed on a daily basis through the irrigation water, according to the recommendation by Miranda et al. (2011). Additionally, the following fertilizers were used to prepare the nutrient solution: $\mathrm{Ca}\left(\mathrm{NO}_{3}\right)_{2}(0.87 \mathrm{~g} / \mathrm{L}), \mathrm{KNO}_{3}(0.30 \mathrm{~g} / \mathrm{L})$, $\mathrm{K}_{2} \mathrm{SO}_{4}(0.18 \mathrm{~g} / \mathrm{L}), \mathrm{MgSO}_{4+} 7 \mathrm{H}_{2} \mathrm{O}(0.33 \mathrm{~g} / \mathrm{L})$, MAP $(0.24 \mathrm{~g} / \mathrm{L}), \mathrm{Fe}$ (chelate) $(47 \mathrm{mg} / \mathrm{L})$, $\mathrm{MnSO}_{4+} 7 \mathrm{H}_{2} \mathrm{O}(3.8 \mathrm{mg} / \mathrm{L}), \mathrm{CuSO}_{4+} 7 \mathrm{H}_{2} \mathrm{O}$ (1.5 mg/L), $\mathrm{ZnSO}^{3}{ }_{4+} 7 \mathrm{H}_{2} \mathrm{O}(1.4 \mathrm{mg} / \mathrm{L}), \mathrm{H}_{3} \mathrm{BO}_{3}$ $(4.1 \mathrm{mg} / \mathrm{L}), \mathrm{Na}_{2} \mathrm{MoO}_{4}(0.13 \mathrm{mg} / \mathrm{L})$.

\section{Analysis}

Plants were collected $120 \mathrm{~d}$ after the transplanting and analyzed for the following components of fruit yield and quality.

Fruit yield. Number of fruits per plant (the fruits were harvested twice a week) and total fruit weight per plant $(\mathrm{kg})$ were determined by an analytical balance (UW Series; Shimadzu, Kyoto, Japan) and the values were expressed in grams; fruit cross and length diameter was determined by digital micrometer (11112AB; Pantec, Nuremberg, Germany) and the values expressed in centimeters; and fruit total yield and the values were expressed in kilograms.

Fruit quality. Pulp firmness was evaluated by means of a digital penetrometer (FT 327; McCormick, MD) and the values expressed in Newton $(\mathrm{N})$. Soluble solids content was determined with the aid of digital refractometer (PR-1000; ATAGO, Yushima, Japan) and the values expressed in $\mathrm{Brix}^{\circ}$; titratable acidity was determined by titration and $\mathrm{pH}$ was determined with a digital potentiometer (the seeds were removed from the fruits and they were homogenized in a blender) (DMPH; Digimed, São Paulo, Brazil). The vitamin $C$ neutralization was determined by titration with DFI solution (2.6 dichlorophenolindophenol $0.02 \%$ ) and the values expressed in $\mathrm{mg} / 100 \mathrm{~g}$ of citric acid; fruit color was determined by the digital colorimeter
(CR-400/410; KONICA MINOLTA, Tokyo, Japan) and lycopene and $\beta$-carotene were determined by the method of Nagata and Yamashita (1992), and the values expressed in $\mu \mathrm{g} \cdot \mathrm{g}^{-1}$.

\section{Statistical analyses}

The parameters evaluated were analyzed using a normality test as described by Kolmogorow-Smirnov and Shapiro-Wilk. A multiple comparison between means by the Tukey test followed an individual ANOVA for each character at 0.05 level of significance. The statistical analysis was performed using the Sisvar 5.3 software (Ferreira, 2011).

\section{Results}

The variables, fruit cross diameter (FCD), fruit length diameter (FLD), fruit number per plant (FNP), average fruit fresh weight (AFFW), fruit total yield per plant (FTY), pulp firmness $(\mathrm{PF}), \mathrm{pH}, \mathrm{Brix}^{\circ}$, titratable acidity (TA), vitamin $\mathrm{C}$ content (VIT C), color relation $\left(\mathrm{a}^{*} / \mathrm{b}^{*}\right)$, lycopene content $(\mathrm{LP})$, and $\beta$-carotene content $(\beta \mathrm{T})$ exhibited significant responses.

Fruit yield. No changes were observed in FCD among T2, T3, T4, T5, and T6 treatments, showing that the PRSI and the T1 (control) had the same efficiency (Table 1). However, T4 and T5 treatments showed high FCD when compared with T6 treatment (4.64, 4.66 and $4.1 \mathrm{~cm}$, respectively) (Table 1 ).

All treatments exhibited the same FLD values when compared with $\mathrm{T} 1$, and the highest values were observed for T4 with the use of PRSI (Table 1). Conversely, FNP (Table 1) was unaffected by salt treatments in which plants were irrigated by just one type of water during the plant life cycle, and all treatments exhibited FNP similar to control (T1 treatment).

$\mathrm{T} 1, \mathrm{~T} 4$, and $\mathrm{T} 5$ treatments exhibited the highest values for AFFW (78.27, 74.83, and $76.00 \mathrm{~g}$, respectively) with no statistically significant results. T6 treatment exhibited a decreased AFFW of $42.58 \%$ when compared with the T1 treatment (control), and to the T4 and T5 treatments, which exhibited decreased AFFW of $39.94 \%$ and $40.86 \%$, respectively. Furthermore, the S2 salinity level drastically reduced the AFFW when it was applied alone (T2) (Table 1), thus demonstrating a negative effect of salinity.

Higher FTY values (Table 1) were observed in T1, T4, and T5 treatments (1739.64, 1663.29, and $1495.23 \mathrm{~g}$, respectively). Among all the treatments under the PRSI system, T6 had the lowest yield, exhibiting a reduction of $51.63 \%$ when compared with the control treatment (T1), as well as $\mathrm{T} 4$ (49.4\%) and T5 (43.7\%) treatments.

Fruit quality. Statistically significant fruit pulp $\mathrm{pH}$ results were observed for T1 (4.20) and T5 (4.00) treatments, while other treatments, T2, T3, T4, and T6, showed no statistically significant results, exhibiting $\mathrm{pH}$ values of 4.06 (T2), 4.06 (T3), 4.05 (T4), and 4.16 (T6), respectively. However, these $\mathrm{pH}$ pulp values were in a regular level for the tomato crop (Table 2).

PF was significantly affected by the applied treatments. In fact, the T2 treatment exhibited the highest value, $50.02 \mathrm{~N}$, an increase of $24 \%$ compared with the $\mathrm{T} 1$ treatment (control). T5 treatment exhibited $\mathrm{PF}$ values similar to T2 treatment (Table 2).

For Brix ${ }^{\circ}$ analysis, T2, T3, T4, T5, and T6 treatments exhibited statistically significant results when compared with $\mathrm{T} 1$ treatment (control). However, among all the treatments under the PRSI system, T4 and T6 treatments exhibited a decreased Brix of 4.95 and 4.90, respectively, when compared with $\mathrm{T} 2$ treatment (5.84) (Table 2).

Following titratable acidity (TA) analyses (Table 2), T1, T2, and T3 treatments exhibited no statistically different values. Only T3 (0.35) was statistically different from T4, T5, and T6 (Table 2), in which the lowest TA values were observed $(0.30,0.29$, and 0.29 , respectively).

The average values found for vitamin $\mathrm{C}$ content (Table 3 ) were not statistically different for the T2, T3, T4, T5, and T6 treatments $(22.9,21.9,24.5,23.4$, and 23.6 $\mathrm{mg} / 100 \mathrm{~g}$ of citric acid, respectively), while T1 $(19.7 \mathrm{mg} / 100 \mathrm{~g})$ had a lower vitamin C content compared with T4 and T6.

Table 1. Fruit cross diameter (FCD), fruit length diameter (FLD), fruit number per plant (FNP), fruit fresh weight (FFW), and fruit total yield (FTY) of tomato plants irrigated with saline water under partial root-zone saline irrigation (PRSI).

\begin{tabular}{llllll}
\hline Treatments $^{\mathrm{z}}$ & FNP & FCD $(\mathrm{cm})$ & FLD $(\mathrm{cm})$ & FFW $(\mathrm{g})$ & FTY $(\mathrm{kg})$ \\
\hline T1 & $22.2 \mathrm{ab}^{\mathrm{y}}$ & $4.4 \mathrm{ab}$ & $5.9 \mathrm{ab}$ & $78.3 \mathrm{a}$ & $1.7 \mathrm{a}$ \\
T2 & $25.0 \mathrm{a}$ & $4.2 \mathrm{~b}$ & $5.4 \mathrm{ab}$ & $48.6 \mathrm{~b}$ & $1.2 \mathrm{c}$ \\
T3 & $19.5 \mathrm{~b}$ & $4.2 \mathrm{~b}$ & $5.0 \mathrm{~b}$ & $59.5 \mathrm{~b}$ & $1.3 \mathrm{bc}$ \\
T4 & $22.2 \mathrm{ab}$ & $4.6 \mathrm{a}$ & $6.1 \mathrm{a}$ & $74.8 \mathrm{a}$ & $1.7 \mathrm{a}$ \\
T5 & $19.7 \mathrm{~b}$ & $4.7 \mathrm{a}$ & $5.6 \mathrm{ab}$ & $76.0 \mathrm{a}$ & $1.5 \mathrm{ab}$ \\
T6 & $18.5 \mathrm{~b}$ & $4.1 \mathrm{~b}$ & $4.9 \mathrm{~b}$ & $44.9 \mathrm{~b}$ & $0.8 \mathrm{~d}$ \\
Tukey's CV & 4.4 & 0.4 & 1.0 & 12.1 & 0.348 \\
Significance $(P)$ & 0.0021 & 0.0007 & 0.010 & 0.0001 & 0.0001 \\
\hline
\end{tabular}

${ }^{\mathrm{z}}$ Treatments: In T1 (control), T2 (S2 water), and T3 (alternate irrigation system between S1 and S2, with a cycling period of $15 \mathrm{~d}$ for each one), the PRSI was not applied; T4 (irrigation with S1 and S2, adopting the PRSI system from phase II to the phase IV), T5 (irrigation with S1 and S2 in the phase II, alternating in phase III; in phase III the inversion of the remaining water was made until the end of phase IV), and T6 (irrigation with S1 and S2, adopting the PRSI system in the phase II, with the water switched between low and high saline water every $15 \mathrm{~d}$, remaining until the end of the phase IV) treatments were under the PRSI. ${ }^{\mathrm{y}}$ Data in columns followed with different letters are significantly different based on Tukey's mean range test for indicated critical values for comparison (CV) and $\alpha=0.05$ rejection level. 
Changes in $a^{*} / b^{*}$ ratio values (Table 3 ), indicative of color change from green to red in tomato, were not statistically different among T1 (0.67), T3 (0.67), T4 (0.59), and T6 (0.61) treatments.

Analyses of lycopene (Table 3) revealed high content values in T1, T2, T3, T4, and T6 treatments $(82.86,72.65,88.01,73.24$, and $91.81 \mu \mathrm{g} \cdot \mathrm{g}^{-1}$, respectively), wherein the lowest value was exhibited by $\mathrm{T} 5$ treatment $\left(60.62 \mu \mathrm{g} \cdot \mathrm{g}^{-1}\right)$ when compared with $\mathrm{T} 1, \mathrm{~T} 3$, and $\mathrm{T} 6$ treatments.

When the $\beta$-carotene content in fruits were analyzed the T2, T3, T4, and T6 treatments $(29.87,42.11,31.5$, and 31.17 ug. $\mathrm{g}^{-1}$, respectively) exhibited content similar to $\mathrm{T} 1 \mathrm{treatment}\left(39.91 \mathrm{ug} \cdot \mathrm{g}^{-1}\right)$ whereas only T5 treatment (27.97 ug. $\left.{ }^{-1}\right)$ exhibited decreased $\beta$-carotene content when compared with T1 treatment (Table 3 ).

\section{Discussion}

Growth, physiological and biochemical parameters have been recommended to elucidate the mechanisms related to salt stress in plants (Ashraf, 2009). According to the results, the use of the PRSI system is efficient in mitigating salt stress. However, the positive response is dependent on water management in the system, based on the responses of $\mathrm{T} 4$,
T5, and T6 treatments under PRSI. Furthermore, it should be also noted that the T6 treatment showed a negative response for the yield parameters, while the quality parameters were similar for the aforementioned treatments. Significant fruit yield reduction in plants can be explained by the water management applied for the T6 treatment, in which the short intervals alternating water and saline resulted in a salt increase to both sides of root-zone.

Under saline conditions nutritional disorders result from the negative effect of high salinity on nutrient availability, which may promote competitive transport, uptake or partitioning within the plant, causing reduction in crop growth (Demiral, 2005).

When the tomato plants were submitted directly to the higher salinity level (S2), the FCD was drastically reduced in response to the lower FFW, as observed by other authors (Oliveira et al., 2014). When alternative salinity managements (T4 and T5) were adopted, however, the plants did not show reduction in transverse diameter.

The FNP results shown by $\mathrm{T} 2$, $\mathrm{T} 1$, and $\mathrm{T} 4$ treatments could be explained by the different biochemical strategies used by the plants to counteract the deleterious effects of salinity, such as the accumulation, selective exclusion, and uptake control of ions by the

Table 2. Fruit $\mathrm{pH}$, pulp firmness $(\mathrm{PF}), \mathrm{Brix}^{\circ}$, and titratable acidity (TA) of tomato plants irrigated with saline water under partial root-zone saline irrigation (PRSI) system.

\begin{tabular}{llcll}
\hline Treatments $^{\mathrm{z}}$ & $\mathrm{pH}$ & PF (Newton) & Brix $^{\circ}$ & TA \\
\hline T1 & $4.20 \mathrm{a}^{\mathrm{y}}$ & $40.03 \mathrm{~b}$ & $5.11 \mathrm{ab}$ & $0.33 \mathrm{ab}$ \\
T2 & $4.06 \mathrm{ab}$ & $50.02 \mathrm{a}$ & $5.84 \mathrm{a}$ & $0.33 \mathrm{ab}$ \\
T3 & $4.06 \mathrm{ab}$ & $43.35 \mathrm{~b}$ & $5.14 \mathrm{ab}$ & $0.35 \mathrm{a}$ \\
T4 & $4.05 \mathrm{ab}$ & $42.20 \mathrm{~b}$ & $4.95 \mathrm{~b}$ & $0.30 \mathrm{~b}$ \\
T5 & $4.00 \mathrm{~b}$ & $44.44 \mathrm{ab}$ & $4.90 \mathrm{~b}$ & $0.29 \mathrm{~b}$ \\
T6 & $4.16 \mathrm{ab}$ & $42.02 \mathrm{~b}$ & $5.26 \mathrm{ab}$ & $0.29 \mathrm{~b}$ \\
Tukey's CV & 0.162 & 6.2 & 0.85 & 0.04 \\
Significance $(P)$ & 0.0106 & 0.002 & 0.0290 & 0.0009
\end{tabular}

${ }^{\mathrm{z}}$ Treatments: In T1 (control), T2 (S2 water), and T3 (alternate irrigation system between S1 and S2, with a cycling period of $15 \mathrm{~d}$ for each one), the PRSI was not applied; T4 (irrigation with S1 and S2, adopting the PRSI system from phase II to the phase IV), T5 (irrigation with S1 and S2 in the phase II, alternating in phase III; in phase III the inversion of the remaining water was made until the end of phase IV), and T6 (irrigation with S1 and S2, adopting the PRSI system in the phase II, with the water switched between low and high saline water every $15 \mathrm{~d}$, remaining until the end of the phase IV) treatments were under PRSI. ${ }^{\mathrm{y}}$ Data in columns followed with different letters are significantly different based on Tukey's mean range test for indicated critical values for comparison $(\mathrm{CV})$ and $\alpha=0.05$ rejection level.

Table 3. Fruit content values for vitamin $\mathrm{C}$, color, lycopene, and $\beta$-carotene of tomato plants irrigated with salty water under partial root-zone saline irrigation (PRSI) system.

\begin{tabular}{lcccc}
\hline Treatments $^{\mathrm{z}}$ & Vitamin C $(\mathrm{mg} / 100 \mathrm{~g})$ & Color $\left(\mathrm{a}^{*} / \mathrm{b}^{*}\right)$ & Lycopene $\left(\mu \mathrm{g} \cdot \mathrm{g}^{-1}\right)$ & $\beta$-carotene $\left(\mu \mathrm{g} \cdot \mathrm{g}^{-1}\right)$ \\
\hline T1 & $19.70 \mathrm{~b}^{\mathrm{y}}$ & $0.67 \mathrm{a}$ & $82.86 \mathrm{ab}$ & $39.91 \mathrm{ab}$ \\
T2 & $22.87 \mathrm{ab}$ & $0.55 \mathrm{~b}$ & $72.65 \mathrm{abc}$ & $29.87 \mathrm{bc}$ \\
T3 & $21.86 \mathrm{ab}$ & $0.67 \mathrm{a}$ & $88.01 \mathrm{ab}$ & $42.11 \mathrm{a}$ \\
T4 & $24.51 \mathrm{a}$ & $0.59 \mathrm{ab}$ & $73.24 \mathrm{abc}$ & $31.50 \mathrm{abc}$ \\
T5 & $23.45 \mathrm{ab}$ & $0.53 \mathrm{~b}$ & $60.62 \mathrm{c}$ & $27.97 \mathrm{c}$ \\
T6 & $23.65 \mathrm{a}$ & $0.62 \mathrm{ab}$ & $91.81 \mathrm{a}$ & $31.17 \mathrm{bc}$ \\
Tukey's CV & 6.8 & 0.098 & 29.72 & 10.75 \\
Significance $(P)$ & 0.0111 & 0.0007 & 0.006 & 0.0022 \\
\hline
\end{tabular}

${ }^{\mathrm{z}}$ Treatments: In T1 (control), T2 (S2 water), and T3 (alternate irrigation system between $\mathrm{S} 1$ and $\mathrm{S} 2$, with a cycling period of $15 \mathrm{~d}$ for each one), the PRSI was not applied; T4 (irrigation with S1 and S2, adopting the PRSI system from phase II to the phase IV), T5 (irrigation with S1 and S2 in the phase II, alternating in phase III; in phase III the inversion of the remaining water was made until the end of phase IV), and T6 (irrigation with $\mathrm{S} 1$ and S2, adopting the PRSI system in the phase II, with the water switched between low and high saline water every $15 \mathrm{~d}$, remaining until the end of the phase IV) treatments were under PRSI. ${ }^{\mathrm{y}}$ Data in columns followed with different letters are significantly different based on Tukey's mean range test for indicated critical values for comparison (CV) and $\alpha=0.05$ rejection level. roots; osmolyte synthesis; photosynthetic pathway alteration; membrane structure modifications, and antioxidant enzyme activities (Esteves and Suzuki, 2008). However, plants in treatment $\mathrm{T} 2$ did not develop in a similar manner to the $\mathrm{T} 1$ and $\mathrm{T} 4$ treatments, as shown in the FFW results. Blanco and Folegatti (2008) and Medeiros et al. (2012) showed reduced results for the FNP in tomato, and other studies with the Solanaceae family, such as bell pepper and eggplant, showed a drastic reduction in FNP with increased salinity (Leonardo et al., 2007; Oliveira et al., 2014; Silva et al., 2013a, 2013b).

As expected, the T2 treatment showed a drastic reduction of AFFW, which could be associated with the negative effects of the salt stress, such as the lower $\psi_{\mathrm{S}}$, ionic toxicity and nutrient uptake imbalance by the roots (Navarro et al., 2003; Silva et al., 2009; Yildirim et al., 2006). T6 under PRSI also had reduced drastically AFFW, a fact that may be related to the management adopted within this treatment, which may have caused accumulation of salts in the substrate, preventing the absorption of water and nutrients by plants. The PRSI system applied to T4 and T5 may have mitigated the salt stress negative effects, maintaining a fruit weight similar to the T1 treatment (control).

There is a lack of studies about the adoption of PRSI by water management systems; our study showed some promising results for T4 and T5 managements, in which fruit yield was similar to the control treatment. PRSI can be a useful technique to use saline water, even if the system success appears to be dependent on the salinity level and time exposure of roots to the salts of nutrient solution and saline water (Guedes et al., 2015; Koushafar et al., 2011).

The economic efficiency of tomato plant production depends on the right crop management practices by which plants can perform well under salt stress conditions (Ayers and Westcot, 1999; Zhang et al., 2017). Nevertheless, tomato yield and fruit quality reduction has been described in both soil and hydroponic growth managements (AlBusaidi et al., 2009; Bao and Li, 2010; Blanco and Folegatti, 2008; Bustomi Rosadi et al., 2014; Cosme et al., 2011; Freire et al., 2010; Maggio et al., 2007; Oliveira et al., 2007).

The economic value of plant-derived food depends on its quality and the evaluation of consumer acceptance. The results obtained in the present work demonstrated that all fruit parameters analyzed were influenced by the treatments. Under PRSI, the $\mathrm{pH}$ remained at the acceptable level for fruit quality (4 to 6) (Giannakoula and Ilias, 2013; Morgan, 1997; Turhan et al., 2011).

A high salt content can decrease the $\psi_{\mathrm{S}}$ of the soil water and consequently reduce the availability of water and nutrients for plants, which can adversely affect the plant's growth (Alves et al., 2011). It was expected that the T2 treatment would show higher pulp firmness in fruit, because fruit tend to have lower water content as a response to the water 
absorption reduction by the roots. According to Zhongdong et al. (2006), pectins contribute to the firmness and structure of the plant tissue as the main middle lamella component involved in intercellular adhesion, especially when it is associated with cellulose and hemicellulose, becoming the main cementing agent of the cell wall.

The PF results in the current study showed pronounced values in all treatments, which can lead to greater postharvest fruit survival. This was possibly due to water content reduction due to high salinity, preventing increased activity of hydrolytic enzymes, which can promote intense solubilization of the cell wall (Chitarra and Chitarra, 2005).

The Brix $^{\circ}$ is a fraction consisting of acids and sugars and therefore is generally accepted as an important quality trait of fruits, with a high positive correlation with the TA. The changes in composition of sugars and organic acids during ripening may affect the overall nutritive quality and consumer acceptability of the fruits (Ferreira et al., 2006; Ferreira, 2011). Though there was slight increase of $\mathrm{Brix}^{\circ}$ and TA observed in those treatments without the PRSI system, other treatments remained at optimal levels, ranging from 4 to 6 for Brix $^{\circ}$ and 0.3 to 0.4 for TA (Alcántar et al., 1999; George et al., 2004).

In the literature, several studies have shown that both Brix $^{\circ}$ and TA can make considerable gains with increased salinity in the medium (Azarmi et al., 2010; Liu et al., 2014; Zhang et al., 2017). The salt application in irrigation water or the use of moderate saline water could be a strategy to achieve high commercial quality fruits, with increased levels soluble solid content and titrable acidity (Zhang et al., 2017).

The vitamin $\mathrm{C}$ content of many fruits shows significant antioxidant properties, which may contribute to reduced cardiovascular diseases and some types of cancer (Albuquerque and da Silva, 2008). The results from all treatments demonstrated the acceptable level of vitamin $\mathrm{C}$, ranging from 10 to $120 \mathrm{mg} / 100 \mathrm{~g}$, independent of the adopted treatment (Fontes et al., 2004).

The external color of fruit is an important aspect of consumer purchase decisions regarding horticultural products, which can be determined by the ratio of lycopene and $\beta$-carotene pigments in ripening fruits (Campos et al., 2006; Seymour et al., 1993).

Lycopene is responsible for the characteristic deep-red color of ripe tomato, accounting for $\approx 80 \%$ to $90 \%$ of the total pigments, and is considered the major tomato carotenoid (Giannakoula and Ilias, 2013; Helyes et al., 2009). Furthermore, lycopene is a key intermediate in the biosynthesis of many other carotenoids, such as $\beta$-carotene and xanthophylls (Clinton, 1998). The results showed that salinity does not interfere with the levels of lycopene and B-carotene; therefore, it is possible to make use of saline water without reducing one of the main components of the tomato. In addition, some studies have shown that salinity depletion can reduce water and increase carotenoid content as a result of adaptations in plants during stress-conditions (De Pascale et al., 2001; Giannakoula and Ilias, 2013; Krauss et al., 2006; Petersen et al., 1998).

The use of a PRSI system, followed by irrigation management, has been shown in this study to maintain yield and quality of tomato plants, and to be a viable alternative for Supera F1 tomato production. Our findings reinforce the importance of the use of PRSI system followed by the irrigation managements without loss on product quality, such as demonstrated by T4 and T5 water managements.

\section{Literature Cited}

Albuquerque, A.C.S. and A.G. da Silva. 2008. Agricultura tropical: quatro décadas de inovações tecnológicas, institucionais e políticas. $2^{\mathrm{a}}$ ed. Embrapa Informação Tecnológica, Brasília, Brasil.

Al-Busaidi, A., S. Al-Rawahy, and M. Ahmed. 2009. Response of different tomato cultivars to diluted seawater salinity. Asian J. Crop Sci. $1: 77-86$.

Alcántar, G.G., R.M. Villarreal, and S.A. Aguilar. 1999. Tomato growth (Lycopersicon esculentum Mill), and nutrient utilization in response to varying fertigation programs. Acta Hort. 481:385-391.

Ali, M. 2008. Horticulture revolution for the poor: Nature, challenges and opportunities. 22 Dec. 2016. <https://openknowledge.worldbank.org/ handle/10986/9127 >

Alves, F.A.L., S.L.F. Silva, J.A.G. Da Silveira, and V.L.A. Pereira. 2011. Efeito do $\mathrm{Ca}^{2+}$ externo no conteúdo de $\mathrm{Na}+$ e $\mathrm{K}+$ em cajueiros expostos a salinidade. Agraria 6:602-608.

Ashraf, M. 2009. Biotechnological approach of improving plant salt tolerance using antioxidants as markers. Biotechnol. Adv. 27:84-93.

Ayers, R.S. and D.W. Westcot. 1999. A qualidade de água na agricultura. $2^{\mathrm{a}}$ ed. Estudos FAO Irrigação e Drenagem, 29. UFPB, Campina Grande, Brasil.

Azarmi, R., R.D. Taleshmikail, and A. Gikloo. 2010. Effects of salinity on morphological and physiological changes and yield of tomato in hydroponics system. J. Food Agr. Environ. 8:573-576.

Bao, H. and Y. Li. 2010. Effect of stage-specific saline irrigation on greenhouse tomato production. Irr. Sci. 28:421-430.

Blanco, F.F. and M.V. Folegatti. 2008. Doses de N e $\mathrm{K}$ no tomateiro sob estresse salino: III. Produção e qualidade de frutos. Rev. Bras. Eng. Agr. Ambient. 12:122-127.

Bustomi Rosadi, R.A., M.S.T.R. Senge, D. Suhandy, and A. Tusi. 2014. The effect of EC levels of nutrient solution on the growth, yield, and quality of tomatoes (solanum lycopersicum) under the hydroponic system. J. Agr. Eng. Biotechnol. 2:7-12.

Campos, C.A.B., P.D. Fernandes, H.R. Gheyi, F.F. Blanco, C.B. Gonçalves, and S.A.F. Campos. 2006. Yield and fruit quality of industrial tomato under saline irrigation. Sci. Agr. 63: 146-152.

Chitarra, M.I.F. and A.B. Chitarra. 2005. Póscolheita de frutas e hortaliças: fisiologia e manuseio. $2^{\text {a }}$ ed. UFLA, Lavras, Brasil.

Clinton, S.K. 1998. Lycopene: Chemistry, biology, and implications for human health and disease. Nutr. Rev. 56:35-51.

Cosme, C.R., N.D.S. Dias, A.D. Oliveira, E.M. Oliveira, and O.N. Sousa Neto. 2011. Produção de tomate hidropônico utilizando rejeito da dessalinização na solução nutritiva aplicados em diferentes épocas. Rev. Bras. Eng. Agr. Ambient. 15:499-504.

Costa, J.M. and E. Heuvelink. 2004. Protected cultivation rising in China. Fruit \& Veg. Technol. 4:8-11.

De Pascale, S., A. Maggio, V. Fogliano, P. Ambrosino, and A. Ritieni. 2001. Irrigation with saline water improves carotenoids content and antioxidant activity of tomato. J. Hort. Sci. Biotechnol. 76:447-453.

Demiral, M.A. 2005. Comparative response of two olive (Oleaeuropaea L.) cultivars to salinity. Turk. J. Agr. For. 29:267-274.

Ehret, D.L., K. Usher, T. Helmer, G. Block, D. Steinke, B. Frey, T. Kuang, and M. Diarra. 2013. Tomato fruit antioxidants in relation to salinity and greenhouse climate. J. Agr. Food Chem. 61:1138-1145.

Esteves, B.S. and M.S. Suzuki. 2008. Efeito da salinidade sobre as plantas. Oecol. Bras. 12:662-679.

FAO. 2015. Food and Agriculture Organization of the United Nations. 22 Feb. 2017. <http://www. faostat.fao.org>.

Ferreira, M.M.M., G.B. Ferreira, P.C.R. Fontes, and J.P. Dantas. 2006. Qualidade do tomate em função de doses de nitrogênio e da adubação orgânica em duas estações. Hort. Bras. 24:141145.

Ferreira, D.F. 2011. Sisvar: A computer statistical analysis system. Cienc. Agrotec. 35:10391042.

Fontes, P.C.R., J.L. Loures, J.C. Galvão, A.A. Cardoso, and E.C. Mantovani. 2004. Produção e qualidade do tomate produzido em substrato, no campo e em ambiente protegido. Hort. Bras. 22:614-619.

Freire, A.L.O., V.P. Saraiva, J.R.P. Miranda, and G.B. Bruno. 2010. Crescimento, acúmulo de íons e produção de tomateiro irrigado com água salina. Ciênc. Agrár. 31:1133-1144.

George, B., C. Kaur, D.S. Khurdiya, and H.C. Kapoor. 2004. Antioxidants in tomato (Lycopersium esculentum) as a function of genotype. Food Chem. 84:45-51.

Giannakoula, A.E. and I.F. Ilias. 2013. The effect of water stress and salinity on growth and physiology of tomato (Lycopersicon esculentum Mil.). Arch. Biol. Sci. 65:611-620.

Guedes, R.A., F.D.A. De Oliveira, R.C. Alves, A.S. De Medeiros, L.P. Gomes, and L.P. Costa. 2015. Estratégias de Irrigação com Água salina não tomateiro cereja em ambiente protegido Rev. Bras. Eng. Agr. Ambient. 19:913-919.

Helyes, L., A. Lugasi, Á. Pogonyi, and Z. Pék. 2008. Effect of variety and grafting on lycopene content of tomato (Lycopersicon lycopersicum L. Karsten) fruit. Acta Aliment. 38:27-34.

Henareh, M. and G. Hassani. 2014. Effects of transplanting stage of seedling and planting depth on growth and yield of tomato cv. Petoearly ch. Majallah-i Bih/Zirai-i Nahal va Bazr 30:103-113.

IBGE. 2015. Instituto Brasileiro de Geografia e Estatística. 22 Dec. 2017. <http://www.ibge. gov.br/home/>.

Kirda, C., M. Cetin, Y. Dasgan, S. Topcu, H. Kaman, B. Ekici, M.R. Derici, and A.I. Ozguven. 2004. Yield response of greenhouse grown tomato to partial root drying and conventional deficit irrigation. Agr. Water Mgt. 69:191-201

Koushafar, M., A.H. Khoshgoftarmanesh, A. Moezzi, and M. Mobli. 2011. Effect of dynamic unequal distribution of salts in the root environment on performance and Crop Per 
Drop (CPD) of hydroponic-grown tomato. Scientia Hort. 131:1-5.

Krauss, S., W. Schnitzler, J. Grassmann, and M. Woltike. 2006. The influence of different electrical conductivity values in a simplified recirculating soilless system on inner and outer fruit quality characteristics of tomato. J. Agr. Food Chem. 54:441-448.

Leonardo, M., F. Broetto, R.L. Villas Boas, R.S. Almeida, and J.A. Marchese. 2007. Produção de frutos de pimentão em diferentes concentrações salinas. Irriga 12:73-82.

Liu, F.Y., K.T. Li, and W.J. Yang. 2014. Differential responses to short-term salinity stress of heat-tolerant cherry tomato cultivars grown at high temperature. Hort. Environ. Biotechnol. 55:79-90.

Maas, E.V. and G.J. Hoffman. 1977. Crop salt tolerance - Current assessment. J. Irrig. Drain. Div. 103:115-134.

Maggio, A., G. Raimondi, A. Martino, and S. De Pascale. 2007. Salt stress response in tomato beyond the salinity tolerance threshold. Environ. Exp. Bot. 59:276-282.

Medeiros, P.R.F., S.N. Duarte, C.A. Uyeda, E.F.F. Silva, and J.F. Medeiros. 2012. Tolerância da cultura do tomate à salinidade do solo em ambiente protegido. Rev. Bras. Eng. Agr. Ambient. 16:51-55.

Miranda, F.R., A.L.M. Mesquita, M.V.V. Martins, C.M.F. Fernandes, M.I.P. Evangelista, and A.A.P. Sousa. 2011. Produção de tomate em substrato de fibra de coco. Circular técnica. Embrapa Agroindústria Tropical, Fortaleza, Brasil.

Morgan, L. 1997. Hydroponic fruit quality testing. Pratic. Hydrop. Green. 34:21-31.

Nagata, M. and I. Yamashita. 1992. Simple method for simultaneous determination of chlorophyll and carotenoids in tomato fruit. Nippon Shokuhin Kogyo Gakkaishi 39:925-928.
Navarro, J.M., C. Garrido, V. Martínez, and M. Carvajal. 2003. Water relations and xylem transport of nutrients in pepper plants grown under two different salts stress regimes. Plant Growth Regulat. 41:237-245.

Nunes, M.U.C. 2000. Produção de mudas de hortaliças com o uso da plasticultura e do pó de coco. Circular técnica. Embrapa Tubuleiros Costeiros, Aracaju, Brasil.

Oliveira, B.C., M.A. Cardoso, J.D. Oliveira, F.D. Oliveira, and L.F. Cavalcante. 2007. Características produtivas do tomateiro submetido a diferentes níveis de sais, na água de irrigação. Rev. Bras. Eng. Agr. Ambient. 11:11-16.

Oliveira, F.D.A., J.F. De Medeiros, R.C. Alves, P.S. Linhares, A.M. De Medeiros, and M.K. De Oliveira. 2014. Interação entre salinidade da água de irrigação e adubação nitrogenada na cultura da berinjela. Rev. Bras. Eng. Agr. Ambient. 18:480-486.

Petersen, K.K., J. Willumsen, and K. Kaack. 1998 Composition and taste of tomatoes as affected by increased salinity and different salinity sources. J. Hort. Sci. 73:205-215.

Richards, L.A. 1954. Diagnostico y rehabilitacion de suelos salinos y sodicos. Manual de agricultura $\mathrm{N}^{\circ} 60$. Departamento de Agricultura de los Estados Unidos de América.

Seymour, G.B., J.E. Taylor, and G. Tucker (eds.). 1993. Biochemistry of fruit ripening. Chapman and Hall, London, UK.

Silva, E.N., J.A.G. Silveira, C.R.R. Fernandes, A.T.B. Dutra, and R.M. Aragão. 2009. Acúmulo de íons e crescimento de pinhãomanso sob diferentes níveis de salinidade. Rev. Cienc. Agron. 40:240-246.

Silva, E.M., C.J.G.S. Lima, S.N. Duarte, F.S. Barbosa, and R. Maschio. 2013a. Níveis de salinidade e manejo da fertirrigação sobre características da berinjela cultivada em ambiente protegido. Rev. Cienc. Agron. 44:150-158.
Silva, P.F., C.J.G.S. Lima, A.C. Barros, E.M. Silva, and S.N. Duarte. 2013b. Sais fertilizantes e manejo da fertirrigação na produção de tomateiro cultivado em ambiente protegido. Rev. Bras. Eng. Agr. Ambient. 17:1173-1180.

Silva, B.A., A.R. Silva, and L.G. Pagiuca. 2014. Cultivo protegido em busca de mais eficiência produtiva. Horti fruit Brasil. 1:10-18.

Sun, Y., H. Feng, and F. Liu. 2013a. Comparative effect of partial root-zone drying and deficit irrigation on incidence of blossom-end rot in tomato under varied calcium rates. J. Expt. Bot. 64:2107-2116.

Sun, Y., F. Yan, and F. Liu. 2013b. Drying/ rewetting cycles of the soil under alternate partial root-zone drying irrigation reduce carbon and nitrogen retention in the soil-plant systems of potato. Agr. Water Mgt. 128:8591.

Turhan, A., N. Ozmen, M.S. Serbeci, and V. Seniz. 2011. Effects of grafting on different rootstocks on tomato fruit yield and quality. Hort. Sci. (Prague) 38:142-149.

Yang, L., H. Qu, Y. Zhang, and F. Li. 2012. Effects of partial root-zone irrigation on physiology, fruit yield and quality and water use efficiency of tomato under different calcium levels. Agr. Water Mgt. 104:89-94.

Yildirim, E., A.G. Taylor, and T.D. Spittler. 2006. Ameliorative effects of biological treatments on growth of squash plants under salt stress. Scientia Hort. 111:1-6.

Zhang, P., M. Senge, K. Yoshiyama, K. Ito, Y. Dai, and F. Zhang. 2017. Effects of low salinity stress on growth, yield and water use efficiency of tomato under soilless cultivation. J. Irrigation, Drainage Rural Eng. 85:15-21.

Zhongdong, L., W. Guohua, G. Yunchang, and J.F. Kennedy. 2006. Image study of pectin extraction from orange skin assisted by microwave. Carbohydr. Polym. 64:548-552. 